\title{
TEAMS GAMES TOURNAMENT (TGT): IMPROVE MOTIVATION OF STUDYING SOCIAL STUDY ELEMENTARY SCHOOL STUDENTS
}

\section{Dewi Rakhmawati}

SD Negeri Kotagede 5

\section{Sejarah Artikel}

Diterima 20 Oktober 2018

Disetujui 26 Desember 2018

Diterbitkan 31 Desember 2018

\section{Kata Kunci}

Motivasi Belajar, IPS,

TEAMS GAMES

TOURNAMENT (TGT)

\begin{abstract}
Abstrak
This research aims to describe Teams Games Tournament (TGT) to improve motivation of studying social students grade VI SD Negeri Kota Gede 5. Increase the motivation of studying IPS imposes on the results of the study. This research includes class action research model Kemmis and Mc Taggart. The subject in this study are students of class VI SD Negeri Kota Gede 2017-2018 Lesson 5 years. The number of students there are 30 consisting of self-11 male students and female students. The success of researchers this action is marked by changes in the direction of the improvement that is $80 \%$ of students have a very high level of motivation. The results showed that an increase in the learning motivation of students who reach the very high category from $60 \%$ to $90 \%$. The results of the study, IPS also experienced an increase based on the number of students who achieved the KKM of 9 students to 22 students.
\end{abstract}

\section{Cara Mengutip}

Rakhmawati, D. (2018). Tim Permainan Turnament (TGT): Menigkatkan Motivasi Belajar IPS Siswa Sekolah Dasar. DWIJA CENDEKIA Jurnal Riset Pedagogik, 2 (2), 17-20.

Korespondensi Penulis: 


\section{PENDAHULUAN}

Motivasi sebagai salah satu faktor yang mempengaruhi belajar seorang siswa turut menentukan keberhasilan dalam belajar seperti pendapat Mc. Donals dalam Sardiman (2006: 73), motivasi adalah perubahan energi dalam diri seseorang yang ditandai dengan munculnya "feeling" dan didahului dengan tanggapan terhadap adanya tujuan. Berdasarkan pendapat tersebut menunjukkan bahwa motivasi merupakan salah satu hal yang penting, karena jika dalam diri anak didik terdapat motivasi, maka akan timbul semangat dan dorongan untuk belajar lebih giat sehingga akan dapat berhasil dalam proses belajarnya. Apabila motivasinya cukup kuat, maka siswa akan memutuskan untuk melakukan perbuatan belajar. Sebaliknya apabila motivasinya tidak cukup kuat, ia akan memutuskan untuk tidak melakukan perbuatan belajar.

Untuk menumbuhkan motivasi yang kuat pada diri siswa dalam kegiatan pembelajaran, maka guru harus pandai dalam memilih media pembelajaran yang tepat digunakan khususnya dalam mata pelajaran IPS. Menurut Sardjiyo, dkk (2009: 26) IPS merupakan bidang studi yang mempelajari, menelaah, menganalisis gejala dan masalah sosial di masyarakat dengan meninjau berbagai aspek dalam kehidupan. Tujuan dari IPS menurut Awan Mutakin (Supardi, 2011: 185) adalah mengembangkan siswa agar peka terhadap masalah sosial yang terjadi di masyarakat, memiliki sikap mental yang positif terhadap perbaikan segala ketimpangan yang terjadi, dan terampil mengatasi setiap masalah yang terjadi sehari-hari dikehidupannya. Berdasarkan pengertian diatas menunjukkan bahwa dengan mempelajari IPS diharapkan dapar memiliki suatu kepekaan terhadap kehidupan dan keterampilan untuk menghadapi tantangan kehidupan. Sementara menurut Saidiharjo (2004: 109) tujuan dari IPS adalah agar siswa mampu mengembangkan pengetahuan, sikap, dan keterampilan social, yang berguna bagi kemajuan dirinya sebagai individu maupun sebagai anggota masyarakat. Berdasarkan pengalaman selama mengajar, salah satu mata pelajaran yang mengalami beberapa kendala dalam mencapai KKM adalah IImu Pengetahuan Sosial. Proses belajar siswa kelas VI SD Negeri Kotagede 5 di Kota Yogyakarta pada mata pelajaran IPS dirasa kurang optimalnya. Hasil belajar siswa kelas VI pada mata pelajaran IPS ternyata masih rendah, hal tersebut dibuktikan dengan banyaknya siswa yang memperoleh nilai dibawah nilai KKM yang ditentukan yaitu 75. Siswa cepat merasa bosan dan ada juga yang mengantuk. Hal tersebut menandakan bahwa motivasi siswa dalam belajar IPS kurang. Faktor- factor yang mempengaruhi belajar seorang melputi perhatian, minat dan motivasi Slameto (2003: 55-58).

Hamzah B. Uno (2013: 23) menyatakan bahwa motivasi belajar adalah dorongan internal dan eksternal dalam diri siswa yang sedang belajar untuk mengadakan perubahan tingkah laku. Oleh karena itu dapat disimpulkan bahwa motivasi belajar adalah keseluruhan daya penggerak atau pendorong yang membuat siswa melakukan kegiatan belajar sehingga tujuan dari belajar dapat tercapai. Made Wena (2010: 33) mengemukakan bahwa motivasi belajar dapat dilihat melalui beberapa indikator seperti keantusiasan dalam belajar, ketekunan dalam belajar dan keterlibatan siswa dalam kegiatan belajar. Hamzah B. Uno dan Nurdin Mohamad (2012: 253) menyebutkan indikator motivasi belajar siswa yaitu ketekunan siswa menyelesaikan tugas yang diberikan guru. Adapun indikator motivasi belajar IPS yang digunakan dalam penelitian ini merupakan gabungan dari dua pendapat ahli di atas yaitu: 1) keantusiasan siswa dalam belajar, 2) keterlibatan siswa dalam kegiatan belajar, 3) ketekunan siswa dalam belajar, 4) keuletan menghadapi kesulitan yang dijumpai dalam belajar, dan 5) keinginan mendalami materi. 
Upaya untuk menanggulangi permasalahan yang terkait dengan motivasi siswa adalah pemilihan model yang tepat agar pembelajaran menjadi lebih menarik. Penerapan Model Pembelajaran Kooperatif Learning Tipe Teams Games Tournament (TGT) diharapkan dapat menjadi solusi dari hambatan pembelajaran IPS. Menurut Robert E. Slavin (2005: 166) model pembelajaran kooperatif tipe TGT menggunakan permainan akademik. Pada kegiatan turnamen ini, masingmasing kelompok bertanding dengan kelompok lain yang setarakemampuan akademiknya berdasarkan kinerja sebelumnya. Komponen-komponen dalam TGT yang diungkapkan Robert E. Slavin meliputi: Presentasi Kelas, Tim, Game, Turnamen dan Rekognisi Tim. Penelitian ini bertujuan untuk mendeskripsikan penggunaan Model Pembelajaran Kooperatif tipe Teams Games Tournament (TGT) dapat meningkatkan motivasi belajar siswa kelas VI SD Negeri Kotagede 5 pada Mata Pelajaran IPS.

\section{METODE PENELITIAN}

Penelitian ini dilaksanakan untuk meningkatkan motivasi belajar IPS melalui penerapan model pembelajaran kooperatif tipe TGT (Teams Games Tournament) pada siswa kelas VI SD Negeri Kotagede 5 Yogyakarta. Penelitian ini termasuk penelitian tindakan kelas (Classroom action research). Model PTK yang digunakan adalah model Kemmis dan Mc Taggart dengan siklus yang dilakukan secara berulang dan berkelanjutan (siklus spiral). Keempat aspek pokok dalam siklus penelitian tindakan kelas meliputi; perencanaan tindakan,tindakan dan observasi, dan refleksi. Pada penelitian ini terdapat dua variabel. Veriabel pertama adalah variabel terikat yaitu motivasi belajar IPS. Variabel kedua adalah variabel bebas yaitu model pembelajaran tipe TGT. Teknik pengumpulan data yang digunakan dalam penelitian ini adalah observasi dan angket. Penelitian ini menggunakan teknik analisis data secara kuantitatif dengan menggunakan teknik rerata. Data motivasi belajar siswa dalam mata pelajaran IPS di analisis dengan menggunakan persentase.

\section{PEMBAHASAN}

Berikut hasil pre-test pada materi wilayah Indonesia dapat dilihat pada Perkembangan sistem administrasi tabel 1.

Tabel 1. Hasil Pre Test Prestasi Belajar IPS

\begin{tabular}{lc}
\hline Keterangan & Pretest \\
\hline Nilai tertinggi & 89 \\
Nilai terendah & 30 \\
Nilai rata-rata & 60,67 \\
Jumlah siswa tuntas & 9 \\
Persentase ketuntasan & $30 \%$ \\
Jumlah siswa tidak tuntas & 21 \\
Persentase ketidaktuntasan & $70 \%$ \\
\hline
\end{tabular}

Sedangkan untuk hasil motivasi saat kegiatan belajar mengajar yang belajar IPS pada kegiatan pra siklus sama dapat dilihat di table 2 .

diperoleh dari hasil pengamatan pada 
Tabel 2. Kategori motivasi belajar IPS

\begin{tabular}{ccc}
\hline Persentase & Kriteria & $\begin{array}{c}\text { Jumlah } \\
\text { siswa }\end{array}$ \\
\hline $81 \leq \mathrm{p}$ & Sangat Tinggi & 12 \\
$61 \leq \mathrm{p} \leq 80$ & Tinggi & 3 \\
$41 \leq \mathrm{p} \leq 60$ & Sedang & 10 \\
$21 \leq \mathrm{p} \leq 40$ & Rendah & 5 \\
$\mathrm{p} \leq 20$ & Sangat Rendah & 0 \\
\hline
\end{tabular}

Berdasarkan nilai prestasi belajar IPS siklus I, dapat dianalisis belajar IPS siswa siklus I dapat ketuntasan belajar siswa. Ketuntasan dilihat pada tabel 3 .

Tabel 3. Ketuntasan Belajar IPS Siklus I

\begin{tabular}{cccccc}
$\begin{array}{c}\text { Jumlah } \\
\text { Siswa }\end{array}$ & \multicolumn{2}{c}{ Ketuntasan } & \multicolumn{2}{c}{$\begin{array}{c}\text { Presentase } \\
\text { Ketuntasan }\end{array}$} & $\begin{array}{c}\text { Rilai } \\
\text { Rata- } \\
\end{array}$ \\
& T & BT & T & BT & rata \\
\hline 30 & 16 & 14 & $53,33 \%$ & $46,67 \%$ & 75,77 \\
\hline
\end{tabular}

Berdasarkan tabel 3, hasil prestasi belajar IPS menunjukkan bahwa baru $53,335 \%$ siswa yang mencapai KKM. Adapun hasil

observasi motivasi belajar IPS siswa selama proses pembelajaran siklus I seperti yang tertera pada tabel 4 .

Tabel 4. Hasil Observasi Motivasi Belajar IPS Siklus I

\begin{tabular}{ccc}
\hline Persentase & Kriteria & Jumlah siswa \\
\hline $81 \leq p$ & Sangat Tinggi & 19 \\
$61 \leq p \leq 80$ & Tinggi & 5 \\
$41 \leq p \leq 60$ & Sedang & 6 \\
$21 \leq p \leq 40$ & Rendah & 0 \\
$p \leq 20$ & Sangat Rendah & 0 \\
\hline
\end{tabular}

Pada siklus I aktivitas guru dalam menerapkan pembelajaran kooperatif tipe TGT adalah 100 yang secara kualitas berdasarkan kriteria penilaian yang dikembangkan oleh Saifuddin Azwar (2005: 163) berada pada kategori " sangat baik" yakni terletak pada rentang skor $>72$.

Berdasarkan nilai prestasi hasil belajar IPS siklus II, dapat dianalisis ketuntasan belajar siswa. Ketuntasan belajar IPS siswa siklus II dapat dilihat pada table 5 .

Tabel 5. Ketuntasan Belajar IPS Siklus II

\begin{tabular}{|c|c|c|c|c|c|}
\hline $\begin{array}{c}\text { Jumlah } \\
\text { siswa }\end{array}$ & $\mathrm{Ke}$ & san & $\begin{array}{l}\text { Presente } \\
\text { ketuntas }\end{array}$ & & $\begin{array}{c}\text { Nilai rata- } \\
\text { rata }\end{array}$ \\
\hline & $T$ & BT & $\mathbf{T}$ & BT & \\
\hline 30 & 22 & 8 & $73,33 \%$ & $36,67 \%$ & 81,17 \\
\hline
\end{tabular}


Berdasarkan tabel di atas, hasil prestasi belajar IPS menunjukkan bahwa ketuntasan belajar IPS pada pokok bahasan Kenampakan Alam dan keadaan sosial Negara-negara tetangga sebesar $73,33 \%$ dan nilai rata-rata sebesar 81,17. Adapun hasil motivasi belajar IPS dapat dilihat pada table 6 .

Tabel 6. Hasil Observasi Motivasi Belajar IPS Siklus II

\begin{tabular}{ccc}
\hline Persentase & Kriteria & Jumlah siswa \\
\hline $81 \leq p$ & Sangat Tinggi & 27 \\
$61 \leq p \leq 80$ & Tinggi & 3 \\
$41 \leq p \leq 60$ & Sedang & 0 \\
$21 \leq p \leq 40$ & Rendah & 0 \\
$p \leq 20$ & Sangat Rendah & 0 \\
\hline
\end{tabular}

Aktivitas guru dalam menerapkan pembelajaran kooperatif tipe TGT pada siklus II adalah 100 yang secara kualitas berdasarkan kriteria penilaian yang dikembangkan oleh Saifuddin Azwar (2005: 163) berada pada kategori " sangat baik" yakni terletak pada rentang skor $>72$.

Penelitian ini dilaksanakan untuk meningkatkan motivasi belajar IPS melalui penerapan model pembelajaran kooperatif tipe TGT (Teams Games Tournament) pada siswa kelas VI SD Negeri Kotagede 5 Yogyakarta. Penelitian dilakukan selama 2 siklus, siklus pertama terdiri dari 2 pertemuan dan siklus kedua terdiri dari 2 pertemuan. Model Pembelajaran kooperatif tipe TGT dilaksanakan dalam lima tahap yaitu presentasi kelas, belajar kelompok, game, turnamen dan penghargaan.

Berdasarkan hasil observasi motivasi belajar siswa, maka terdapat peningkatan mulai dari pra siklus, siklus 1 dan siklus 2. Pada pra siklus, persentase motivasi belajar IPS yang berada pada ketegori sangat tinggi sebesar $60 \%$, kemudian untuk siklus I meningkat menjadi $63,33 \%$, dan terjadi peningkatan lagi pada siklus II menjadi $90 \%$. Hal itu terjadi karena kondisi belajar yang menarik, sehingga anak menjadi lebih termotivasi untuk melakukan yang kemungkinan bisa dia lakukan karena adanya penghargaan prestasi di meja turnamen berupa kompetisi untuk bisa promosi ke maupun degradasi, sesuai dengan teori Hamzah B. Uno yang menyebutkan motivasi ekstrinsik sebagai motivasi yang timbul karena rangsangan dari luar individu seperti adanya penghargaan, lingkungan belajar yang kondusif, dan kegiatan belajar yang menarik.

Sedangkan untuk motivasi yang berasal dari siswa dapat dilihat dari keinginan untuk bersaing dengan kelompok lain dan berusaha untuk bisa berada di peringkat tinggi ketikan dilakukan aktivitas game atau turnamen. Hal ini sesuai dengan pendapat Hamzah B. Uno yang menyebutkan bahwa motivasi intrinsik adalah motivasi yang telah ada dalam diri individu misalnya keinginan berhasil. Motivasi belajar siswa yang meningkat maka berdampak pada prestasi belajar IPS siswa yang juga mengalami peningkatan. Hal tersebut dapat dilihat dari jumlah siswa yang meningkat dalam mencapai KKM dari pra siklus sebesar $30 \%$, siklus 1 sebesar $53,33 \%$ dan siklus 2 sebesar $73,33 \%$. Peningkatan prestasi belajar IPS tersebut terjadi karena siswa merasa senang ketika menerima materi pelajaran IPS. Hal ini sesuai dengan teori Made Wena bahwa 
motivasi belajar adalah suatu bersemangat, dan senang belajar dorongan internal maupun external secara serius dan terus menerus yang membuat siswa bergerak, selama kegiatan proses belajar.

\section{SIMPULAN}

Peningkatan motivasi belajar IPS terjadi tipe TGT disesuaikan dengan sintaks melalui proses Penerapan Model yang sudah baku, pembagian kelompok Pembelajaran Kooperatif Tipe TGT pada yang dilandasi dengan penjelasan dari kelas VI SD N kotagede 5 Yogyakarta. guru tentang heterogenitas, dan Peningkatan tersebut dapat dilihat pada pemerataan tingkat kesulitan soal yang perolehan skor motivasi belajar IPS pada diberikan kepada setiap kelompok. para siklus sebesar $60 \%$, siklus I sebesar Penggunaan model pembelajaran $66,33 \%$ dan pada siklus II sebesar 90\%. kooperatif tipe TGT perlu memperhatikan Peningkatan itu terjadi karena langkah- tingkat kesulitan soal yang merata dan langkah Model Pembelajaran Kooperatif pembagian kelompok yang heterogen.

\section{DAFTAR PUSTAKA}

Asma, Nur. (2006). Model Pembelajaran Kooperatif. Jakarta: Departemen Pendidikan Nasional Direktorat Jenderal Pendidikan Tinggi.

Departemen Pendidikan Nasional. (2003). Undang-Undang RI No. 20 Tahun 2003 Tentang Sistem Pendidikan Nasional. Jakarta: Direktorat Pendidikan Dasar dan Menengah.

Dimyati \& Mudjiono. (2009). Belajar dan

Pembelajaran. Jakarta: Rineka Cipta.

Hamzah B. Uno. (2013). Teori Motivasi dan Pengukurannya. Jakarta: Bumi Aksara.

\& Nurdin Mohamad. (2012). Belajar dengan Pendekatan Pembelajaran Aktif Inovatif Lingkungan Kreatif Efektif Menarik (PAIKEM). Jakarta: Bumi Aksara.

Made Wena. (2010). Strategi Pembelajaran Inovatif Kontemporer. Jakarta: Bumi Aksara.

$\begin{array}{ccr}\text { Martinis } \quad \text { Yamin. } & \text { (2006). } & \begin{array}{r}\text { Strategi } \\ \text { Perbasis }\end{array} \\ \text { Kompelajaran } & & \text { Getensi. } \\ \text { Persada Press. } & \text { Jakarta: } & \text { Gaung } \\ & \end{array}$

Melvin L Silberman (2004). Active Learning, 101 Cara Belajar Siswa Aktif. Terjemahan Raisul Muttaqien. Bandung: Nusa Media bekerjasama dengan Nuansa

Robert E Slavin (2005). Cooperative Learning Teori, Riset dan Praktek. Jakarta: Nusa Media

Saidiharjo (2004). Diktat Pengembangan Kurikulum IImu Pengetahuan Sosial. Bahan kuliah mahasiswa PPs Universitas Negeri Yogyakarta

Sardiman. (2006). Interaksi \& Motivasi Belajar Mengajar. Jakarta: RajaGrafindo Persada.

Sardjiyo, Didih Sugandi, Ischak (2009). Pendidikan IPS SD. Jakarta: Universitas Terbuka

Slameto. (2003). Belajar dan FaktorFaktor yang Mempengaruhinya. Jakarta: Rineka Cipta 